\title{
ANALISIS MODEL PENGEMBANGAN INFRASTRUKTUR JARINGAN KOMPUTER PADA UNIVERSITAS TEKNOLOGI SUMBAWA SEBAGAI INOVASI MENGGUNAKAN METODE PPDIOO
}

\author{
I Made Widiarta ${ }^{1^{*}}$, Shinta Esabella ${ }^{2}$, Putu Widiantara ${ }^{3}$ \\ ${ }^{*}$ Pasca Sarjana Universitas Teknologi Sumbawa \\ ${ }^{2}$ Fakultas Teknik Universitas Teknologi Sumbawa \\ Corresponding Author email: imade.widiarta@uts.ac.id, shinta.esabella@uts.ac.id, iputuwidiantara@uts.ac.id
}

\begin{abstract}
Abstrak
Diterima :

Tujuan penelitian ini untuk mengembangkan manajemen infrastruktur jaringan komputer Bulan Juni 2020 pada Universitas Teknologi Sumbawa. Penelitian dimulai dengan melakukan analisa pada infrastruktur jaringan komputer yang sedang berjalan, kemudian dilakukan pengembangan manajemen infrastruktur jaringan komputer untuk meningkatkan kinerja manajeman pertukaran data dan informasi. Metode penelitian yang digunakan adalah PPDIOO (Prepare, Plan, Design, Implement, Operate, dan Optimize) yang merupakan

Diterbitkan: Bulan Juli 2020 metode perancangan jaringan dari Cisco sebagai suatu siklus hidup pada layanan jaringan dalam mendukung pengembangan jaringan komputer. Pada Tahap Prepare dilakukan analisis existing infrastruktur yang sudah ada dengan menggunakan tools Net Tools yang tersedia pada Smartphone Android untuk menganalisa ketersediaan Wifi dan menggunakan Host Tracker untuk menguji kestabilan server. Selanjutnya pada tahap Plan dan design dilakukan pengembangan infrastuktur yang telah ada. Hasil tahap Implement

Keyword : Manajemen, Infrastruktur, Jaringan Komputer, akan diuji kembali untuk memastikan infrastruktur jaringan sudah beroperasi secara optimal. Adapun Hasil penelitian menunjukkan bahwa area yang tidak terjangkau WiFi (Blank Spot) sudah semakin berkurang. Ketersediaan server juga telah memiliki Up Time diatas 99,9\%. Sehingga dapat disimpulkan dalam penelitian ini, bahwa dengan menggunakan perancangan infrastuktur yang baru mampu memberikan ketersediaan PPDIOO jaringan yang lebih optimal untuk mendukung program Smart Campus pada Universitas Teknologi Sumbawa.
\end{abstract}

\section{PENDAHULUAN}

Perkembangan industri 4.0 menuntut percepatan penerapan teknologi informasi hampir di seluruh sektor usaha. Begitu juga dengan bidang pendidikan, untuk menuju kampus yang memiliki daya saing harus di dukung oleh infrastruktur teknologi informasi yang tepat, baik dalam bentuk perangkat keras atau perangkat lunak untuk mendukung pelayanan yang efektif dan efisien

Universitas Teknologi Sumbawa merupakan sebuah kampus teknologi yang berlokasi di Sumbawa. Berdasarkan rencana strategis unit IT tahun 2019, Universitas Teknologi Sumbawa memiliki rencana jangka panjang menjadi sebuah Smart Campus.

Salah satu manifestasi dalam penerapan smart campus yaitu penggunaan berbagai macam sistem informasi untuk mendukung pelayanan yang optimal. Penarapan sistem informasi tersebut tentunya harus didukung oleh infrastruktur yang optimal.

Berdasarkan hasil observasi penulis, saat ini infrastrukur jaringan yang di miliki oleh
Universitas Teknologi Sumbawa masih belum mampu mencakupi seluruh gedung yang ada di kampus. Baru $76 \%$ gedung yang sudah memiliki fasilitas internet, hal ini tentu berdampak pada proses belajar mengajar dan pelayanan yang menjadi kurang optimal. Seluruh sistem juga masih menggunakan server on-promises. Berdasarkan observasi penulis, up-time server yang berlokasi di kampus hanya berkisar $85 \%$, itu artinya dalam rentang waktu satu minggu, server tersebut rata-rata tidak bisa diakses selama 33.6 jam. Tentunya hal ini juga akan berdampak buruk terhadap pelayanan.

Namun, hal tersebut bisa diatasi dengan menggunakan Cloud Server. Cloud server merupakan pemanfaatan teknologi komputer yang berbasis internet di mana semua data dapat disimpan pada server yang ada di internet. Penggunaan cloud server ini akan sangat membantu operasional kampus. Beberapa faktor yang akan lebih optimal dengan penggunaan cloud adalah Ketersediaan, Keamanan, Biaya, Fleksibilitas dan Otomatisasi. Ketersediaan, server tersedia selama 24/7 sepanjang tahun tanpa harus khawatir akan ketersediaan listrik. 
Keamanan Maksimal, Cloud tersedia sebuah team yang terdiri dari security expert yang memonitor aktivitas sebuah sistem sepanjang hari dan sepanjang tahun. Jadi, kemungkinan data penting diakali, hacked, dicuri, ataupun corrupt akan sangat berkurang. Hemat Biaya, dikutip dari katalog yang disediakan oleh telkomsel, sebuah provider internet menawarkan layanan premium dengan private IP per bulan berkisar antara Rp. 910.000 s.d Rp. 1.800.000 dengan bandwidth hanya 1 MBPS. Biaya tersebut belum termasuk investasi terhadap server yang relative mahal. Dikutip dari, sebuah server rack mounting standar dengan spesifikasi Intel Xeon $3,5 \mathrm{GHz}$ dan RAM 8GB berkisar antara Rp. 21.000.000 s.d. 30.000.000. Cloud memberikan harga yang lebih terjangkau, dikutip dari price list yang dikeluarkan oleh Dewa Web dengan spesifikasi processor yang sama biaya yang harus dikeluarkan per bulan antara Rp. 300.000 s.d Rp. 600.000. Fleksibilitas, dengan Cloud server perubahan secara cepat bisa dilakukan untuk menyesuaikan kebutuhan. Ketika perusahaan memerlukan server dengan kapasitas lebih besar, maka di menit itu juga Cloud sudah menyanggupi kebutuhannya.

Berdasarkan uraian permasalahan di atas, penulis mencoba melakukan analisa dan perancangan Infrastuktur Jaringan untuk mandukung Implementasi Smart Campus, dimana penelitian ini diawali dengan menganalisis infrastruktur jaringan komputer yang telah digunakan hingga saat ini di seluruh bangunan, mengukur stabilitas server yang tersedia, kemudian melakukan perancangan infrastuktur jaringan komputer yang baru, selanjutnya menganalisis perbadingan ketersediaan jaringan antara sebelum dilakukan pengembangan dengan setelah dilakukan pengembangan.

\section{LANDASAN TEORI}

Dalam penyusunan proposal thesis dengan judul Analisa dan Perancangan Infrastruktur Jaringan untuk Mendukung Implementasi Smart Campus di Universitas Teknologi Sumbawa, penulis menggunakan beberapa penelitian terdahulu yang disusun berdasarkan sumber yang valid untuk dijadikan acuan dan landasan sebagai pendukung penelitian yang dibuat.

Ricky Wiranata "Analsisis Kualitas Sinyal pada Antena Rooftop Menggunakan Software Tems Investiagation". Dalam penelitian ini dilakukan pengukuran terhadap kualitas sinyal dengan menggunakan Tems Investigation. Teradapat kesesuaian dengan yang dilakukan peneliti saat ini, yaitu melakukan pengukuran kulitas sinyal dari suatu daerah. Namun terdapat perbedaan dengan tools yang digunakan oleh peneliti Ricky Wiranata, dimana Ricky Wiranata melakukan penelitian menggunakan software Tems Investigation, sedangkan peneliti menggunakan software Wifi Analyzer.

\section{Teori yang mendukung pendekatan masalah}

\section{Cloud Computing}

Cloud computing terdiri dari dua kata yaitu Cloud dan Computing. Cloud biasa diartikan sebagai awan yang dimaksud awan ini adalah internet sedangkan Computing adalah proses komputasi. Cloud computing adalah perkembangan terkini dari client server. Aplikasi dan file di simpan di awan terserbut terdiri dari ratusan atau bahkan ribuan komputer yang terhubung bersama-sama dan bias diakses melalui internet (Wahana, 2011).

Cloud computing atau komputasi awan ialah teknologi yang memanfaatkan layanan internet menggunakan pusat server yang bersifat virtual dengan tujuan pemeliharaan data dan aplikasi (Syaikhu, 2010). Menurut (ELCOM, 2012) dijelaskan bahwa Cloud computing adalah gabungan antara pemanfaatan teknologi komputer dengan pengembangan berbasis internet.

Cloud computing dapat diartikan sebagai teknologi komputer yang menggunakan internet sebagai medianya. Cloud computing memanfaatkan kemampuan pemrosesan dari banyak komputer antar jaringan yang kemampuannya dapat disesuaikan dengan kebutuhan pengguna. Intinya kebutuhan yang harus ada untuk menggunakan cloud computing adalah sebuah komputer dan koneksi internet.

Tidak semua aplikasi berbasis web dapat dimasukkan ke dalam kategori cloud computing. Ada lima kriteria yang harus dipenuhi oleh sebuah sistem untuk bisa di masukkan dalam keluarga cloud computing, NIST (National Institute of Standards and Technology) mengidentifikasi lima karakteristik yaitu (Mell, 2011) :

\section{a. Swalayan (On-demand self-service)}

Pengguna dapat menetapkan sendiri kualitas dan kuantitas layanan yang dibutuhkan tanpa perlu bertatap muka langsung dengan pihak penyedia layanan. Semua dilakukan sesuai kehendak pengguna melalui jaringan internet.

\section{b. Akses Pita Lebar (Broad network access)}

Kemampuan yang tersedia melalui jaringan dan dapat diakses melalui melalui berbagai perangkat seperti telepon selular, laptop dan PDA (Personal Digital Assistant).
c. Sumber daya Terkelompok (Resource pooling)
Penyatuan sumberdaya komputasi yang
dimiliki penyedia untuk melayani beberapa 
konsumen menggunakan model multi-penyewa, Mekanisme multi-penyewa ini memungkinkan sejumlah sumberdaya komputasi digunakan secara bersama-sama oleh sejumlah user, dimana sumberdaya tersebut dapat dialokasikan secara dinamis untuk kebutuhan pengguna/pelanggan sesuai permintaan.

\section{d. Elastis (Rapid elasticity)}

Kemampuan dapat dengan cepat dan elastis ditetapkan. Kemampuan untuk menambah atau mengurangi sumber daya yang digunakan dapat dilakukan secara cepat dan efisien. Dengan demikian, kemampuan cloud computing seolah-olah kapasitas yang tersedia tidak terbatas besarnya dan dapat dibeli kapan saja dengan jumlah berapa saja.

\section{e. Layanan Terukur (Measured Service)}

Sistem cloud computing secara otomatis mengawasi dan mengoptimalkan penggunaan sumber-daya dengan memanfaatkan kemampuan pengukuran (metering). Penggunaan sumber daya dapat diawasi, dikontrol, dan dilaporkan sehingga memberikan ketransparanan kepada penyedia layanan maupun pengguna layanan.

\section{Teori yang menjelaskan variabel penelitian}

a. Availability

Availability merupakan ukuran seberapa lama suatu service atau komponen-komponen dari service dapat segera digunakan. Availability merupakan properti yang digunakan sistem untuk tetap beroperasi bahkan ketika terjadi kegagalan proses. Availability dapat juga didefinisikan sebagai kemungkinan bahwa sistem akan beroperasi dengan benar dalam waktu tertentu dan dapat menjalankan fungsinya bagi kepentingan client.

Availability selalu terkait dengan Service Level Agreement (SLA). SLA terdiri dari beberapa bagian yang mendefinisikan tanggung jawab terhadap tingkat ketersediaan layanan. Tingkat ketersediaan sistem diukur dari jumlah angka Sembilan (9). Semakin sedikit angka sembilan pada tingkat ketersediaan sistem maka semakin rendah pula availability sistem tersebut. Untuk aplikasi pada umumnya memiliki presentasi uptime 99\% sudah dapat dianggap layak. Perbandingan availability layanan terhadap presentase uptime ditunjukkan oleh Tabel 1.

\begin{tabular}{|c|c|c|c|}
\hline $\begin{array}{l}\text { Presentase } \\
\text { Uptime (\%) }\end{array}$ & $\begin{array}{c}\text { Presentase } \\
\text { Downtime (\%) }\end{array}$ & $\begin{array}{c}\text { Downtime } \\
\text { pertahun }\end{array}$ & $\begin{array}{l}\text { Downtime } \\
\text { perminggu }\end{array}$ \\
\hline 98 & 2 & 7.3 hari & 3 jam 22 menit \\
\hline 99 & 1 & 3.65 hari & 1 jam 41 menit \\
\hline 99,8 & 0,2 & 17 jam 30 menit & 20 menit 10 detik \\
\hline 99,9 & 0,1 & 8 jam 45 menit & 10 menit 5 detik \\
\hline 99,99 & 0,01 & 52.5 menit & 1 menit \\
\hline 99,999 & 0,001 & 5.25 menit & 6 detik \\
\hline 99,9999 & 0,0001 & 31.5 detik & 0.6 detik \\
\hline
\end{tabular}

Dilihat pada tabel di atas, tingkat availability sebuah layanan yang baik yaitu memiliki downtime per minggu maksimal 1 jam 41 menit.

\section{MATODE PENELITIAN}

Desain penelitian yang digunakan adalah Prepare, Plan, Design, Implement, Operate dan Optimize (PPDIOO) yang merupakan metode perancangan jaringan dari Cisco sebagai suatu siklus hidup pada layana jaringan dalam mendukung pengembangan jaringan komputer.

Berikut tahap-tahap analisis pada metode PPDIOO:

\section{A. Prepare (Persiapan)}

Pada tahapan prepare (persiapan), merupakan menetapkan kebutuhan organisasi dan bisnis, yang digunakan untuk mengembangkan strategi jaringan dan mengusulkan konsep arsitektur jaringan dengan level tingkat tinggi, untuk mendukung suatu strategi yang didukung dengan kemampuan keuangan pada organisasi atau perusahaan tersebut.

\section{B. Plan (Perancanaan)}

Pada tahapan Plan (perencanaan) melakukan identifikasi persyaratan suatu jaringan yang berdasarkan tujuan, fasilitas serta kebutuhan jaringan yang akan dibuat. Fase ini mendeskripsikan karakteristik suatu jaringan, yang bertujuan untuk menilai jaringan tersebut, serta melakukan gap analisis pada perancangan yang terbaik pada sebuah arsitektur dengan melihat serta mempertimbangkan perilaku dari lingkungan operasional. Sehingga sebuah perencanaan proyek dikembangkan untuk mengelola tugas-tugas (Tasks), dan pihak-pihak yang bertanggung jawab, batu pijakan (Milestone), dan semua sumber daya untuk melakukan desain dan implementasi. Perancanaan proyek harus sejalan dengan ruang lingkup (batasan), biaya dan parameter sumber daya yang disesuaikan dengan kebutuhan bisnis. Rencana proyek ini diikuti dan diperbarui selama tahap-tahap dalam siklus.

\section{Design (Desain)}

Pada tahapan Design jaringan yang dikembangkan berdasarkan persyaratan teknis serta bisnis yang telah diperoleh dari kondisi sebelumnya. Spesifikasi desain jaringan adalah desain yang harus bersifat komprehensif dan terperinci, agar dapat memenuhi persyaratan teknis dan bisnis saat ini. Jaringan tersebut haruslah senantiasa menyediakan ketersediaan, kehandalan, keamanan, skalabilitas dan kinerja. Hasil dari desain ini termasuk diagram jaringan, dan daftar peralatan-peralatan. Rencana proyek harus terus diperbarui dengan informasi yang lebih terperinci untuk diimplementasikan. Setelah tahap desain disetujui, tahap implementasi dimulai. 


\section{Implement (Implementasi)}

Pada tahapan ini, peralatan-peralatan baru dilakukan instalasi dan dikonfigurasi sesuai spesifikasi desain. Perangkat - perangkat yang baru ini disiapskan untuk mengganti atau menambah peralatan infrastruktur yang ada. Perancanaan proyek juga harus diikuti selama tahap ini, jika ada perubahan seharusnya disampaikan dalam pertemuan (Meeting) dengan persetujuan yang diperlukan untuk dilanjutkan. Setiap langkah dalam implementasi harus menyertakan deskripsi, rincian pedoman pelaksanaan, perkiraan waktu untuk penerapan, evaluasi (Rollback) langkah-langkah jika terdapat kegagalan, dan informasiinformasi lainnya sebagai referensi tambahan. Seiring perubahan yang telah di implementasikan, tahapan ini juga menjadi langkah pengujian sebelum pindah ke fase Operasional (Operate Phase).

\section{E. Operate (Operasional)}

Pada tahapan Operasional adalah mempertahankan kegiatan sehari-hari jaringan. Operasional meliputi pengelolaan dan monitor komponen-komponen jaringan, pemeliharaan Routing, mengelola kegiatan Upgrade, mengelola kinerja, mengidentifikasi dan mengoreksi kesalahan jaringan. Tahap ini adalah ujian akhir bagi tahapan desain. Selama operasi, manajemen jaringan harus memantau stabilitas dan kinerja jaringan, deteksi kesalahan, koreksi konfigurasi dan kegiatankegiatan pemantauan kinerja yang menyediakan data awal untuk fase selanjutnya, yaitu fase optimalisasi (Optimize Phase).

\section{F. Optimize (Optimalisasi)}

Pada tahapan optimalisasi melibatkan kesadaran proaktif seorang manajer jaringan dengan mengidentifikasi dan menyelesaikan masalah, sebelum persoalan tersebut mempengaruhi jaringan. Fase optimalisasi memungkinkan untuk memodifikasi desain jaringan, jika terlalu banyak masalah jaringan yang timbul, kemudian juga untuk memperbaiki masalah kinerja atau untuk menyelesaikan masalah-masalah pada aplikasi (Software). Persyaratan-persyaratan untuk desain jaringan yang dimodifikasi mengarahkan perkembangan jaringan tersebut, kembali ke awal siklus hidup dalam model fase PPDIOO.

\section{HASIL DAN PEMBAHASAN}

\section{Hasil Penelitian}

Berikut adalah hasil penelitian berdasarkan tahapan-tahapan metodologi pekerjaan yang digunakan diantaranya:

\section{i. Prepare (Tahap Persiapan)}

Pada tahapan ini dimulai dari melakukan pengecekan terhadap perangkat-perangkat yang dibutuhkan untuk proses analisis dan perancangan project itu sendiri. Adapun hal-hal yang telah dilakukan antara lain:

\section{a. Obeservasi Bangunan}

Berdasarkan hasil observasi terhadap system yang sudah berjalan, di kampus Universitas Teknologi Sumbawa terdapat 49 ruang kelas dan 25 gedung yang dapat dilihat pada tabel 4.1 berikut :

Tabel 1 Data Gedung

\begin{tabular}{|c|c|c|}
\hline No & Gedung & Luas \\
\hline 1 & Gedung Orange & $665 \mathrm{~m}^{2}$ \\
\hline 2 & Gedung Karim & $242 \mathrm{~m}^{2}$ \\
\hline 3 & Gedung BTN & $148,5 \mathrm{~m}^{2}$ \\
\hline 4 & Gedung BRI 2 & $148,5 \mathrm{~m}^{2}$ \\
\hline 5 & Gedung BNI 2 & $148,5 \mathrm{~m}^{2}$ \\
\hline 6 & Gedung PLN & $148,5 \mathrm{~m}^{2}$ \\
\hline 7 & Gedung Mandiri & $148,5 \mathrm{~m}^{2}$ \\
\hline 8 & Gedung Pertamina & $148,5 \mathrm{~m}^{2}$ \\
\hline 9 & Gedung PGN & $148,5 \mathrm{~m}^{2}$ \\
\hline 10 & Gedung Semen Gresik & $148,5 \mathrm{~m}^{2}$ \\
\hline 11 & Mushola & $36 \mathrm{~m}^{2}$ \\
\hline 12 & Rektorat & $827 \mathrm{~m}^{2}$ \\
\hline 13 & Gedung Kuliah BRI & $219 \mathrm{~m}^{2}$ \\
\hline 14 & Gedung Kuliah BNI & $219 \mathrm{~m}^{2}$ \\
\hline 15 & Gedung Dikti & $336 \mathrm{~m}^{2}$ \\
\hline 16 & Gedung Newmont & $189 \mathrm{~m}^{2}$ \\
\hline 17 & Laboratorium & $178 \mathrm{~m}^{2}$ \\
\hline 18 & LAboratorium 2 & $178 \mathrm{~m}^{2}$ \\
\hline 19 & Masjid Kampus & $131,3 \mathrm{~m}^{2}$ \\
\hline 20 & Perpustakaan & $192 \mathrm{~m}^{2}$ \\
\hline 21 & Laboratorium Teknik & $60 \mathrm{~m}^{2}$ \\
\hline 22 & $\begin{array}{l}\text { Mini GOR UTS dan } \\
\text { lahan }\end{array}$ & $1.359 \mathrm{~m}^{2}$ \\
\hline 23 & $\begin{array}{l}\text { Gedung PGN Kantor } \\
\text { RPK }\end{array}$ & $54 \mathrm{~m}^{2}$ \\
\hline 24 & Gedung Asrama & $1.000 \mathrm{~m}^{2}$ \\
\hline 25 & Gedung Asrama Putri & $1.000 \mathrm{~m}^{2}$ \\
\hline
\end{tabular}

\section{b. Obeservasi Ketersediaan Jaringan}

Obeservasi dilakukan dengan cara mengukur kekuatan Wifi di setiap gedung yang ada di Unviersitas Teknologi Sumbawa. Tools yang digunakan adalah Aplikasi Wifi Analyzer yang dapat diunduh di play store. Hasil dari survey ini adalah: 


\begin{tabular}{|c|c|c|c|}
\hline No & Gedung & $\begin{array}{c}\text { Ketersediaan } \\
\text { Jaringan }\end{array}$ & $\begin{array}{l}\text { Kekuata } \\
\text { n Sinyal }\end{array}$ \\
\hline 1 & $\begin{array}{l}\text { Gedung } \\
\text { Orange }\end{array}$ & Tersedia & Kurang \\
\hline 2 & $\begin{array}{l}\text { Gedung } \\
\text { Karim }\end{array}$ & Tersedia & Baik \\
\hline 3 & $\begin{array}{l}\text { Gedung } \\
\text { BTN }\end{array}$ & Tersedia & Baik \\
\hline 4 & $\begin{array}{l}\text { Gedung BRI } \\
2\end{array}$ & Tersedia & Baik \\
\hline 5 & $\begin{array}{l}\text { Gedung BNI } \\
2\end{array}$ & Tersedia & Baik \\
\hline 6 & $\begin{array}{l}\text { Gedung } \\
\text { PLN }\end{array}$ & Tersedia & Baik \\
\hline 7 & $\begin{array}{l}\text { Gedung } \\
\text { Mandiri }\end{array}$ & Tersedia & Baik \\
\hline 8 & $\begin{array}{l}\text { Gedung } \\
\text { Pertamina }\end{array}$ & Tersedia & Baik \\
\hline 9 & $\begin{array}{l}\text { Gedung } \\
\text { PGN }\end{array}$ & $\begin{array}{c}\text { Tidak } \\
\text { Tersedia }\end{array}$ & - \\
\hline 10 & $\begin{array}{l}\text { Gedung } \\
\text { Semen } \\
\text { Gresik }\end{array}$ & $\begin{array}{c}\text { Tidak } \\
\text { Tersedia }\end{array}$ & - \\
\hline 11 & Mushola & Tersedia & Baik \\
\hline 12 & Rektorat & Tersedia & Kurang \\
\hline 13 & $\begin{array}{l}\text { Gedung } \\
\text { Kuliah BRI }\end{array}$ & Tersedia & Baik \\
\hline 14 & $\begin{array}{l}\text { Gedung } \\
\text { Kuliah BNI }\end{array}$ & Tersedia & Baik \\
\hline 15 & $\begin{array}{l}\text { Gedung } \\
\text { Dikti }\end{array}$ & Tersedia & Baik \\
\hline 16 & $\begin{array}{l}\text { Gedung } \\
\text { Newmont }\end{array}$ & Tersedia & Baik \\
\hline 17 & $\begin{array}{l}\text { Laboratoriu } \\
\mathrm{m}\end{array}$ & $\begin{array}{c}\text { Tidak } \\
\text { Tersedia }\end{array}$ & - \\
\hline 18 & $\begin{array}{l}\text { Laboratoriu } \\
\text { m } 2\end{array}$ & Tersedia & Baik \\
\hline 19 & $\begin{array}{l}\text { Masjid } \\
\text { Kampus }\end{array}$ & Tersedia & Baik \\
\hline 20 & $\begin{array}{l}\text { Perpustakaa } \\
\text { n }\end{array}$ & Tersedia & Baik \\
\hline 21 & $\begin{array}{l}\text { Laboratoriu } \\
\text { m Teknik }\end{array}$ & $\begin{array}{c}\text { Tidak } \\
\text { Tersedia }\end{array}$ & Baik \\
\hline 22 & $\begin{array}{l}\text { Mini GOR } \\
\text { UTS dan } \\
\text { lahan }\end{array}$ & $\begin{array}{c}\text { Tidak } \\
\text { Tersedia }\end{array}$ & Baik \\
\hline 23 & $\begin{array}{l}\text { Gedung } \\
\text { PGN Kantor } \\
\text { RPK }\end{array}$ & $\begin{array}{c}\text { Tidak } \\
\text { Tersedia }\end{array}$ & Baik \\
\hline 24 & $\begin{array}{l}\text { Gedung } \\
\text { Asrama }\end{array}$ & Tersedia & Baik \\
\hline 25 & $\begin{array}{l}\text { Gedung } \\
\text { Asrama Putri }\end{array}$ & Tersedia & Baik \\
\hline 26 & $\begin{array}{l}\text { Gedung } \\
\text { Belakang } \\
\text { Orange }\end{array}$ & $\begin{array}{c}\text { Tidak } \\
\text { Tersedia }\end{array}$ & - \\
\hline
\end{tabular}

Tabel 2 Data Ketersediaan Jaringan

c.

Beradasarkan data pada tabel 2 baru terdapat 20 gedung dari total 26 gedung atau sekitar $76 \%$ area gedung yang tercover Wifi.

\section{d. Obeservasi Ketersediaan Server}

Obeservasi dilakukan dengan menggunakan tools Host Tracker yang disediakan oleh hostracker.com. Berdasarkan Obeservasi, diperoleh hasil:

Tabel 3 Data Ketersediaan Server

\begin{tabular}{|c|l|l|l|}
\hline No. & Server & Bulan & $\begin{array}{l}\text { Up } \\
\text { Time }\end{array}$ \\
\hline 1 & $\begin{array}{l}\text { Lenovo Server } \\
\text { X3100 }\end{array}$ & September & $87 \%$ \\
\hline 2 & $\begin{array}{l}\text { PC BuildUp Core } \\
\text { i3 }\end{array}$ & September & $87 \%$ \\
\hline 3 & $\begin{array}{l}\text { Lenovo Server } \\
\text { X3100 }\end{array}$ & Oktober & $85 \%$ \\
\hline 4 & $\begin{array}{l}\text { PC BuildUp Core } \\
\text { i3 }\end{array}$ & Oktober & $85 \%$ \\
\hline 5 & $\begin{array}{l}\text { Lenovo Server } \\
\text { X3100 } \\
\text { PC BuildUp Core } \\
\text { i3 }\end{array}$ & Nopember & $82 \%$ \\
\hline
\end{tabular}

Dari data di atas terlihat ketersediaan server belum maksimal. Rata-rata uptime masih 85,66\%.
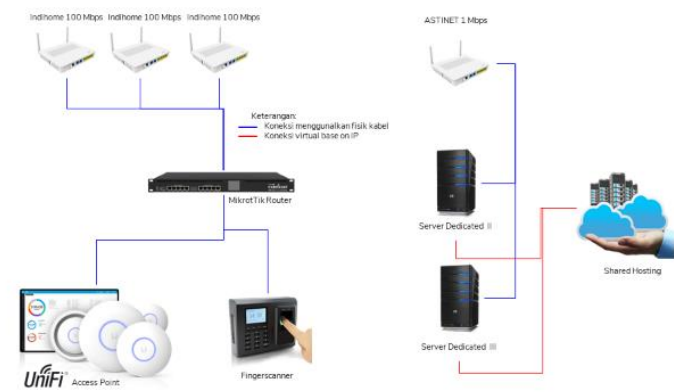

Gambar 1 Network Topology yang sedang berjalan

Dari gambar 1 terlihat bahwa hampir seluruh layanan masih terinstall di server on promises. Hal ini berdampak pada ketergantungan terhadap listrik yang tersedia. Semakin sering terjadi pemadaman listrik maka akan berdampak semakin terhambatnya layanan. 


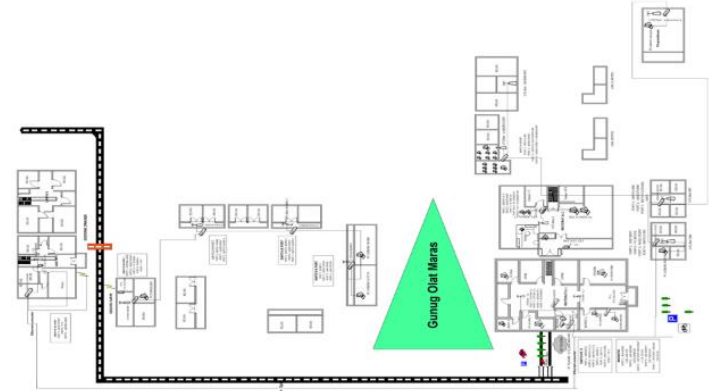

Gambar 2 Network Architecture yang sedang berjalan

Dari gambar 2 terlihat masih ada beberapa gedung yang belum terjangkau jaringan internet.

\section{ii. Plan (Tahap Perencanaan)}

Pada tahap ini dilakukan tahapan perencanaan dimana pada tahapan ini adalah menggambarkan segala jenis kebutuhan yang akan dibutuhkan pada saat pelaksanaan pekerjaan yang berkaitan dengan hal analisis dan pengembangan jaringan komputer.

Pada aktivitas ini dilakukan pengumpulan dan penetapan akan kebutuhan Perangkat keras Jaringan Komputer yang nantinya diperlukan sebagai bahan pengembangan jaringan komputer. Pada penetepan kebutuhan ini ada beberapa peralatan jaringan yang akan digunakan dalam implementasi pengembangan jaringan komputer. Adapun perangkat yang dibutuhkan untuk pengembangan jarignan yaitu Unifi Access Point HD, Switch Gigabit, Kabel UTP, Konektor RJ 45 dan cloud Server.

iii. Design (Tahap Desain)

Pada tahap ini dilakukan pembuatan seluruh arsitektur dan topologi jaringan secara detail yang akan digunakan pada Perancangan Arsitektur Jaringan. Adapun aktivitas yang dilakukan adalah sebagai berikut:

\section{a. Perancangan Topologi Jaringan}

Pada aktivitas ini dalam perancangan ini desain topologi jaringan yang digunakan adalah topologi star. Topologi star ini berpusat pada switch sebagai terminal dan Mikrotik sebagai penghubung jaringan untuk menghubungkan beberapa segmen jaringan yang berbeda dan sebagai penghubung perangkat keras jaringan komputer lainnya agar dapat terhubung kedalam jaringan sekaligus sebagai media penghubung jaringan dari satu ruangan ke ruangan lainnya. Berikut ini perancangan topologi jaringan yang akan digunakan.

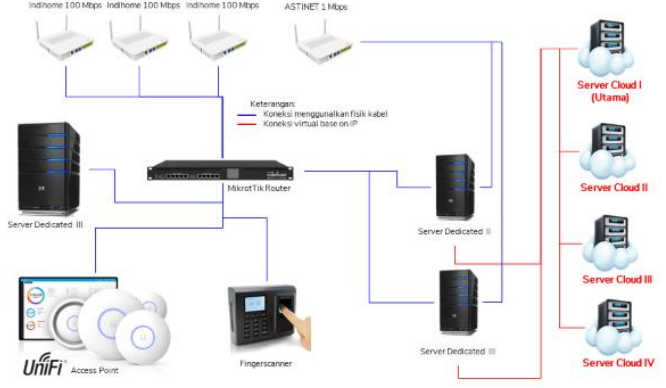

Gambar 3 Network Topologi

Dari topologi di atas terlihat penggunaan server VPS berbasis Cloud mulai diimplementasikan. Hampir seluruh layanan dipindahkan ke dalam server cloud

\section{b. Perancangan Arsitektur Jaringan}

Pada aktivitas ini menampilkan denah gedung serta arsitektur jaringan seperti pada gambar berikut ini:

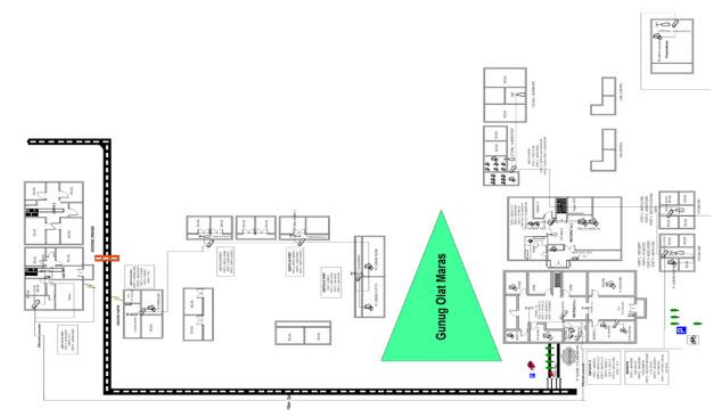

Gambar 4 Arsitektur Jaringan

Dari gambar di atas terlihat penambahan jaringan baru di beberapa gedung. Dilakukan juga penambahan Access Point di beberapa gedung dengan jumlah pengguna yang relatif banyak. Berdasarkan hasil perhitungan, perancangan ini mampu meminimalisir terjadinya area tanpa sinyal atau blank spot.

iv. Implement (Tahap Implementasi)

a. Instalasi Jaringan.

Pada aktivitas ini dilakukan pemasangan perangkat jaringan dan pembuatan kabel jaringan yang sekaligus sebagai media penghubung antara perangkat keras yang satu dengan yang lainnya. 


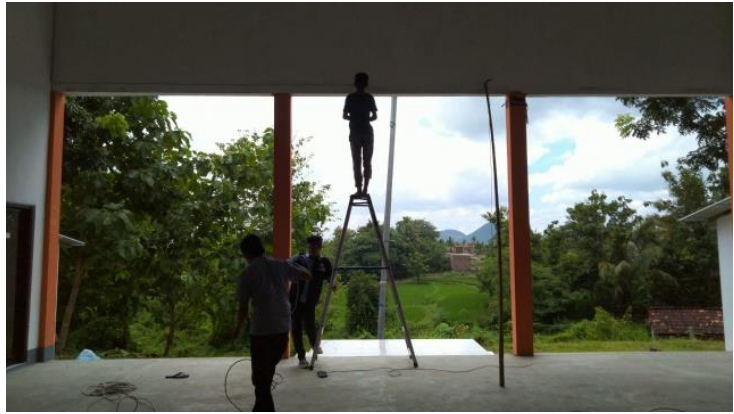

Gambar 4 Instalasi Jaringan

Proses instalasi pada gedung yang belum terjangkau jaringan Wifi. Access Point diletakkan di bagian atas plafon agar sebaran sinyal menjadi merata.

b. Melakukan Konfigurasi Jaringan.

Pada aktivitas ini dilakukan konfigurasi pada seluruh perangkat keras jaringan yang akan digunakan diantaranya Melakukan konfigurasi pada mikrotik. konfigurasi pada acsess point yang digunakan untuk seluruh ruangan, acsess point untuk hotspot, dan konfigurasi Personal Computer.

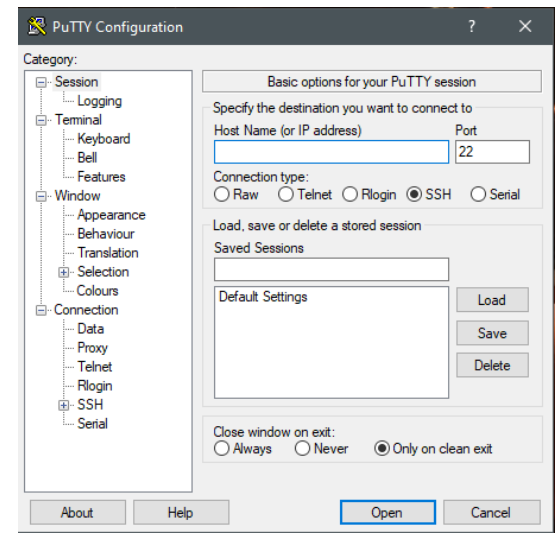

Gambar 4 Konfigurasi Jaringan Menggunakan Putty

Konfigurasi jaringan ke dalam MikroTik dan Cloud Server menggunakan layanan SSH, sehingga tools yang digunakan adalah Putty.

v. Operate (Tahap Operasional)

a. Menerapkan Sistem Monitoring Jaringan.

Pada aktivitas ini penerapan sistem monitoring pada Perancangan arsitektur jaringan ini yaitu menggunakan tools Unifi Controller yang merupakan software gratis dari Ubiquity yang secara otomatis dapat meningkatkan cara mengelola area lingkungan jaringan yang sedang digunakan. Dan akan memindai semua perangkat unifi Access Point, menarik pada tata letak peta jaringan, memonitor layanan perangkat jaringan dan melakukan tindakan berdasarkan perubahan status perangkat. tidak hanya dapat memantau perangkat Acces Point, tetapi juga dapat melakukan estimasi kekuatan sinyal.

Tabel 3 Data Ketersediaan Wifi

\section{[HostTracker] Monthly report Inbox x}

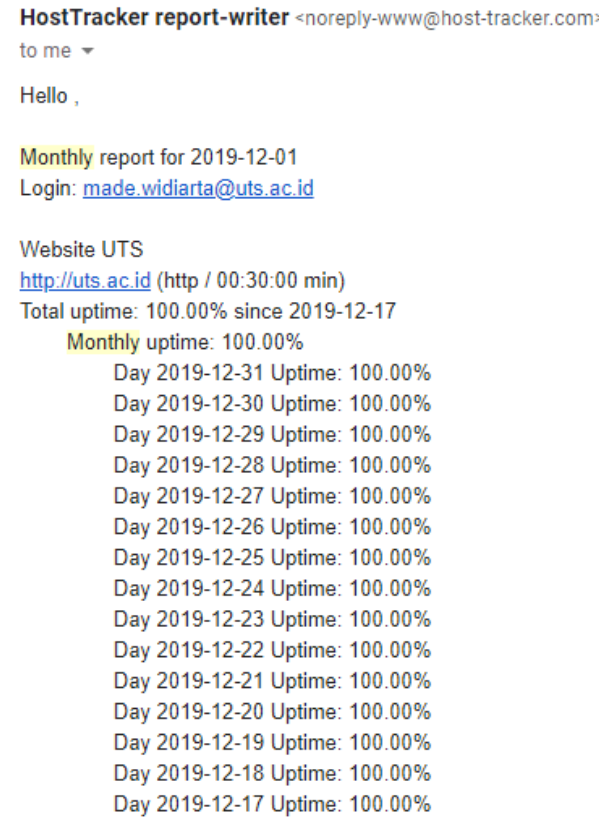

Gambar 5 Monthly report dari Host Tracker

\begin{tabular}{|c|l|l|l|}
\hline No. & Server & Bulan & $\begin{array}{l}\text { Up } \\
\text { Time }\end{array}$ \\
\hline 1 & Server uts.ac.id & Januari & $100 \%$ \\
\hline 2 & Server uts.ac.id & Pebruari & $99.21 \%$ \\
\hline 3 & Server uts.ac.id & Maret & $99.52 \%$ \\
\hline
\end{tabular}

Berdasarkan laporan tersebut dapat dilihat setelah pemindahan data di Cloud, uptime server rata-rata menjadi $99.57 \%$.

\section{b. Melakukan Pemeliharaan.}

Pada aktivitas ini dilakukan pemeliharaan dan perawatan terhadap seluruh komponen perangkat keras jaringan serta perangkat lunak jaringan, berikut aktivitas yang dilakukan diantaranya Melakukan pengecekan pada perangkat Modem ISP, Mikrotik, Access point, Hub/Switch, serta Melakukan pengecekan pada Aplikasi Unifi Controller. 


\begin{tabular}{|c|c|c|c|}
\hline $\begin{array}{l}\mathbf{N} \\
\mathbf{o}\end{array}$ & Gedung & $\begin{array}{c}\text { Ketersediaa } \\
\text { n Jaringan }\end{array}$ & $\begin{array}{l}\text { Kekuata } \\
\text { n Sinyal }\end{array}$ \\
\hline 1 & $\begin{array}{l}\text { Gedung } \\
\text { Orange }\end{array}$ & Tersedia & Kurang \\
\hline 2 & $\begin{array}{l}\text { Gedung } \\
\text { Karim }\end{array}$ & Tersedia & Baik \\
\hline 3 & Gedung BTN & Tersedia & Baik \\
\hline 4 & $\begin{array}{l}\text { Gedung BRI } \\
2\end{array}$ & Tersedia & Baik \\
\hline 5 & $\begin{array}{l}\text { Gedung BNI } \\
2\end{array}$ & Tersedia & Baik \\
\hline 6 & Gedung PLN & Tersedia & Baik \\
\hline 7 & $\begin{array}{l}\text { Gedung } \\
\text { Mandiri }\end{array}$ & Tersedia & Baik \\
\hline 8 & $\begin{array}{l}\text { Gedung } \\
\text { Pertamina }\end{array}$ & Tersedia & Baik \\
\hline 9 & Gedung PGN & Tersedia & Baik \\
\hline 10 & $\begin{array}{l}\text { Gedung } \\
\text { Semen } \\
\text { Gresik }\end{array}$ & Tersedia & Baik \\
\hline 11 & Mushola & Tersedia & Baik \\
\hline 12 & Rektorat & Tersedia & Baik \\
\hline 13 & $\begin{array}{l}\text { Gedung } \\
\text { Kuliah BRI }\end{array}$ & Tersedia & Baik \\
\hline 14 & $\begin{array}{l}\text { Gedung } \\
\text { Kuliah BNI }\end{array}$ & Tersedia & Baik \\
\hline 15 & $\begin{array}{l}\text { Gedung } \\
\text { Dikti }\end{array}$ & Tersedia & Baik \\
\hline 16 & $\begin{array}{l}\text { Gedung } \\
\text { Newmont }\end{array}$ & Tersedia & Baik \\
\hline 17 & $\begin{array}{l}\text { Laboratoriu } \\
\mathrm{m}\end{array}$ & Tersedia & Baik \\
\hline 18 & $\begin{array}{l}\text { Laboratoriu } \\
\text { m } 2\end{array}$ & Tersedia & Baik \\
\hline 19 & $\begin{array}{l}\text { Masjid } \\
\text { Kampus }\end{array}$ & Tersedia & Baik \\
\hline 20 & $\begin{array}{l}\text { Perpustakaa } \\
\mathrm{n}\end{array}$ & Tersedia & Baik \\
\hline 21 & $\begin{array}{l}\text { Laboratoriu } \\
\text { m Teknik }\end{array}$ & $\begin{array}{c}\text { Tidak } \\
\text { Tersedia }\end{array}$ & Baik \\
\hline 22 & $\begin{array}{l}\text { Mini GOR } \\
\text { UTS dan } \\
\text { lahan }\end{array}$ & $\begin{array}{c}\text { Tidak } \\
\text { Tersedia }\end{array}$ & Baik \\
\hline 23 & $\begin{array}{l}\text { Gedung PGN } \\
\text { Kantor RPK }\end{array}$ & $\begin{array}{c}\text { Tidak } \\
\text { Tersedia }\end{array}$ & Baik \\
\hline 24 & $\begin{array}{l}\text { Gedung } \\
\text { Asrama }\end{array}$ & Tersedia & Baik \\
\hline 25 & $\begin{array}{l}\text { Gedung } \\
\text { Asrama } \\
\text { Putri }\end{array}$ & Tersedia & Baik \\
\hline 26 & $\begin{array}{l}\text { Gedung } \\
\text { Belakang } \\
\text { Orange }\end{array}$ & $\begin{array}{c}\text { Tidak } \\
\text { Tersedia }\end{array}$ & - \\
\hline
\end{tabular}

\begin{tabular}{|c|l|l|l|}
\hline No. & $\begin{array}{c}\text { Lokasi } \\
\text { Pengujian }\end{array}$ & $\begin{array}{c}\text { Server } \\
\text { Lama }(\mathbf{m s})\end{array}$ & $\begin{array}{c}\text { Server } \\
\text { Baru }(\mathbf{m s})\end{array}$ \\
\hline 1 & US (W) & 212 & 185 \\
\hline 2 & US (E) & 268 & 245 \\
\hline 3 & London & 236 & 186 \\
\hline 4 & Singapore & 37 & 16 \\
\hline 5 & Sao Paulo & 382 & 366 \\
\hline 6 & Bangalore & 96 & 71 \\
\hline 7 & Sydney & 126 & 106 \\
\hline 8 & Japan & 103 & 85 \\
\hline 9 & Canada & 282 & 236 \\
\hline 10 & Germany & 243 & 183 \\
\hline
\end{tabular}

Pengujian kecepatan Responses Times dilakukan menggunakan tools yang disediakan oleh Bitcatcha.com. Kecepatan diuji melalui 10 negara, antara lain United States (West), United States (East), London, Singapore, Sao Paulo, Bangalore, Sydney, Japan, Canada, dan Jerman.

vi. Optimize (Tahap Optimalisasi)

a. Melakukan Modifikasi

Pada aktivitas ini yang dilakukan adalah merubah atau memaksimalkan suatu perangkat atau sistem jaringan agar lebih optimal diantaranya:

- Mengubah tampilan log in page pada halaman Hotspot.

- Menambahkan gelombang $5 \mathrm{Gz}$ untuk area yang ramai.

\section{Pembahasan}

Dari hasil pengembangan jaringan yang dilakukan didapatkan data bahwa total 24 dari 26 gedung atau sekitar $92 \%$ gedung di UTS sekarang telah dalam proses terhubung Wifi. Sebelum dilakukan pengembangan jaringan, sebaran kualitas sinyal Access Point yang belum maksimal. Gedung dengan penghuni yang rutin berada di dalamnya memiliki perangkat yang sama dibandingkan dengan gedung yang gedung dengan penghuni yang relatif kurang banyak. Setelah dilakukan distribusi ulang perangkat, penyebaran sinyal menjadi lebih optimal. Perangkat dengan spesifikasi lebih tinggi 
ditempatkan di lokasi dengan pengguna aktif lebih banyak. Hampir seluruh gedung saat ini telah memiliki jaringan Wifi.

Terdapat satu gedung yang belum terjangkau Wifi adalah Gedung RPK. Hal ini disebabkan karena jarak Gedung RPK ke pusat Switch terdekat lebih dari 100 meter dan tidak ada media untuk memasang atau menggantung kabel jaringan. Penggunaan gelombang radio sebagai pengganti kabel membutuhkan investasi yang cukup besar sehingga pengembangan jaringan hingga ke gedung RPK masih membutuhkan waktu lebih lama.

Unifi Controller menjadi tools utama dalam melakukan monitoring perangkat. Melalui Unifi Controller, administrator dapat mengetahui perangkat yang aktif atau tidak aktif. Begitu juga dengan performa dari setiap perangkat, administrator dapat mengetahui perangkat yang memiliki beban paling banyak dan resource paling banyak digunakan. Sehingga memudahkan dalam proses pengelolaan dan maintenance perangkat.

Lebar bandwidth yang digunakan pada on promises server adalah 5 mbps. Pada server on promises tersebut terinstal lebih dari lima aplikasi yang relatif sering digunakan dan pengguna yang banyak. Hal ini berdampak pada akses server yang menjadi lebih lambat karena harus melayani lebih banyak request diwaktu yang bersamaan. Melalui penggunaan cloud server, lebar bandwidth ditingkatkan menjadi up to $1000 \mathrm{mbps}$.

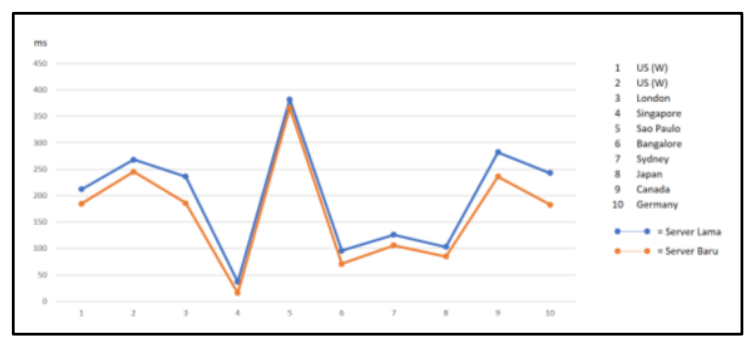

Gambar 1 Perbandingan Responses Time

Berdasarkan hasil pengujian, responses time pada server cloud lebih cepat dibandingkan pada on promises server. Hal ini disebabkan karena server cloud memiliki mirror di beberapa region negara. Sehingga jarak yang dibutuhkan untuk terhubung ke sebuah host menjadi relatif lebih pendek.

Penyebab utama rendahnya uptime pada saat menggunakan on promises server adalah masih seringnya terjadi pemadaman listrik. Sehingga berdampak pada server yang ikut mati dan mengakibatkan beberapa komponen server menjadi memiliki resiko rentan rusak. Perubahan topologi jaringan dengan lebih mengoptimalkan cloud server berdampak pada tingginya uptime pada server tersebut.

Aplikasi Sistem Informasi Sumberdaya Terintegrasi (SISTER) belum berhasil dipindahkan ke server cloud karena paket instalasi yang diperoleh dalam bentuk Virtual Machine. VPS Cloud provider yang digunakan saat ini tidak mengizinkan menjalankan mesin VPS di dalam mesin VPS.

Berdasarkan hasil dari pengembangan arsitekur menjadi server cloud terjadi peningkatan uptime server dari 85,66 \% menjadi 99,57\%. Terjadi peningkatan sebesar $14 \%$ karena cloud server mampu mengatasi masalah yang sering terjadi pada on promiseses server, yaitu pemadaman listrik.

Dalam satu bulan masih terdapat downtime selama $0,47 \%$ atau sekitar 3 jam 23 menit. Jika dirataratakan per hari maka diperoleh hasil 6,8 menit. Penulis mengamati berdasarkan catatan log yang tersimpan di server, downtime 6,8 menit disebabkan oleh server yang melakukan restart saat terjadi update software.

\section{PENUTUP}

\section{Kesimpulan}

Berdasarkan hasil pembahasan dan tinjauan teori yang telah dilakukan dapat disimpulkan bahwa Pengembangan Manajemen Infrastruktur Jaringan Komputer pada Universitas Teknologi Sumbawa dengan menggunakan metode Prepare, Plan, Design, Implement, Operate, dan Optimize (PPDIOO) mampu memberikan ketersediaan jaringan yang lebih optimal untuk mendukung program Smart Campus pada Universitas Teknologi Sumbawa. Area yang sudah terkoneksi wifi meningkat dari yang sebelumnya $76 \%$ area yang menjadi $92 \%$. Ketersediaan layanan juga mengalami peningkatan, terjadi peningkatan uptime server sebesar $14 \%$ dari yang sebelumnya $85 \%$ meningkat menjadi $99 \%$. Tentunya, hal ini menunjukkan bahwa inovasi ini perlu dukungan infrastruktur listrik yang memadai untuk memenuhi kebutuhan bisnis proses di Universitas Teknologi Sumbawa.

\section{Saran-saran}

Pengembangan Manajemen Infrastruktur Jaringan Komputer yang dilakukan oleh peneliti masih belum menggunakan metode backup yang ideal. Diharapkan penelitian selanjutnya mampu merancang system dengan teknologi backup yang terbaru misalnya dengan menerapkan teknik RAID mulai dari level satu hingga level enam. 


\section{REFERENSI}

Cordiaz, Muhammad. 2017. Penerapan Smart Campus sebagai Pendukung Kegiatan Pendidikan dalam Tri Dharma Perguruan Tinggi. Dalam Jurnal Informatika Universitas Pamulang. Vol. 2, No. 2.

Garnis, Aishah. Suroso. Sopian Soim. 2017. Pengkajian Kualitas Sinyal dan Posisi Wifi Access Point dengan Metode RSSI di Gedung KPA Politeknik Negeri Sriwijaya. Dalam Prosiding SNATIF ke-4.

Ginting, Misalina. 2018. Pemanfaatan Cloud Computing pada Aplikasi E-Learning. Dalam Jurnal Teknik Informatika Unika St. Thomas, Volume 03 No. 01. ISSN: 2548-1916

Irawan, Bambang. 2015. Pengembangan Laboratorium Komputer Terpadu Universitas Esa Unggul dengan Metode PPDIOO. Dalam Jurnal Ilmu Komputer, Volume 11 Nomer 2, Hal. 81.

Lukitasari, Desy dan Ahmad Fali Oklilas. 2010. Analisis Perbandingan Load Balancing Web Server Tunggal dengan Web Server Cluster Menggunakan Linux Virtual Server. Dalam Jurnal Generic Universitas Sriwijaya. Vol. 5 No. 2.

N.W. Arsa, Gusti. 2015. Analisis Sistem Cloud Computing IAAS Penyedia Server Cloud dengan Standar NIST Special Publication 800-145". Dalam Jurnal Sistem dan Informatika STMIK STIKOM Bali, P-ISSN: 1858-473X, e-ISSN: 2460-3732.
P. Mell dan T.Grance. 2011. The NIST Definition of Clod Compting Recommendation of the National Institute of Standards an Technology. NIST Spec. Publ. 800-145.

Purnomo, Joko dan S. W. Edi. 2017. Implementasi dan Analisis High Availability Server dengan Teknik Failover Clustering Menggunakan Heartbeat. Skripsi. Universitas Kristen Satya Wacana.

Rochman, Saepul dkk. 2015. Perancangan Arsitektur Jaringan ekolah Menengah Kejuruan Dengan Menerapkan Konsep The Dude Server." Dalam Jurnal Algoritma Sekolah Tinggi Teknologi Garut. P-ISSN: 1412-3622, EISSN: 2302-7339.

S. Wilkins. 2011. Cisco's PPDIOO Network Cycle, Cisco Press. Leuttu.

Syaikhu Akhmad. 2010. Komputasi Awan (Cloud Computing) Perpustakaan Pertanian. Dalam Jurnal Pustakawan Indonesia pada Pusat Perpustakaan dan Penyebaran Teknologi Pertanian. Volume 10. No. 1.

Wahana Komputer. 2011. Kupas Tuntas BermacamAplikasi Generasi Coloud Computing. Andi Offset Yogyakarta.

Wiranata, Ricky. 2019. Analsis Kualitas Sinyal Pada Antena Rooftop Menggunakan Software Tems Investigation". Dalam Jurnal Teknik Elektro Universitas Tanjungpura, volume 2, No. 1.

Yutanto, Hariadi. 2015. Manajemen Tata Kelola Captive Portal Hotspot MikroTik \& Unifi Controller. Dalam Jurnal NARODROID Perbanas Surabaya. Vol. 1, No. 2 Juli. 